\title{
POTENSI HASIL BEBERAPA AKSESI LAMTORO SEBAGAI SUMBER HIJAUAN MAKANAN TERNAK (HMT)
}

\author{
Dwi Pangesti Handayani, Wenny Ayunisa, Winda Nawfetrias, Juwartina, dan Ida Royani \\ Badan Pengkajian dan Penerapan Teknologi, Serpong, Tangerang Selatan \\ email: dwi.pangesti@bppt.go.id
}

\begin{abstract}
ABSTRAK
Lamtoro (Leucaena leucocephala L.) merupakan salah satu pakan berserat yang digunakan untuk memenuhi kebutuhan pakan ternak dengan edible portion berupa daun dan batang muda. Setiap daerah memiliki keragaman morfologi serta potensi hasil lamtoro yang berbeda. Penelitian ini bertujuan untuk mengetahui potensi beberapa aksesi lamtoro sebagai hijauan makanan ternak berdasarkan keragaan morfologi serta bobot edible portion. Penelitian disusun dalam rancangan acak kelompok (RAK) dengan tiga taraf perlakuan aksesi lamtoro (NTT, Yogyakarta, Serpong) dan delapan ulangan. Hasil penelitian menunjukkan bahwa perlakuan aksesi lamtoro berpengaruh nyata terhadap parameter tinggi tanaman, bobot basah dan bobot kering edible portion. Berdasarkan keragaan morfologi tanaman diketahui bahwa aksesi Serpong dapat digunakan sebagai sumber HMT untuk pemberian pakan dengan bantuan manusia, sedangkan aksesi NTT dan Yogyakarta berpotensi sebagai HMT untuk ternak gembalaan.
\end{abstract}

Kata kunci: aksesi lamtoro, HMT, potensi hasil

POTENTIAL PRODUCTIVITY OF LAMTORO ACCESSIONS AS FORAGES

\begin{abstract}
Lamtoro (Leucaena leucocephala L.) is a fibrous plant for animal feed with young leaves and stems as edible portions. Every region has their own morphological diversity and potential productivity. The aim of this study was to determine the potential of lamtoro accessions as a forage based on morphological performance and weight of edible portion. The experiment was arranged in a randomized block design with three levels of lamtoro accessions (NTT, Yogyakarta, Serpong) and eight replications. The results showed that lamtoro accessions significantly affected for plant height, wet weight and dry weight of edible portion. Based on the performance of plant morphology it showed that the accession of Serpong can be used as forage for feeding with human assistance, while accessions for NTT and Yogyakarta potential to be forages for grazing.
\end{abstract}

Keyword: forages, lamtoro accession, potential productivity

\section{PENDAHULUAN}

Pertambahan jumlah penduduk di Indonesia mempengaruhi peningkatan kebutuhan daging nasional dimana saat ini negara kita masih mengimpor daging sapi sebesar 28\% dari konsumsi nasional atau sekitar 195.850 ton dari 686.270 ton (BPS, 2020). Peningkatan permintaan daging harus diikuti dengan pemenuhan kuantitas dan kualitas pakan ternak untuk menunjang produktivitas ternak. Pengelolaan ternak di Indonesia umumnya dilakukan oleh masyakarat dalam skala kecil dengan pemberian pakan hijauan sebagai pakan utama. Hijauan pakan ternak dibedakan menjadi dua famili besar yaitu graminaeae dan leguminosae. Leguminosae merupakan hijauan sumber protein (Prihantono et al., 2017). Salah satu legume yang memiliki kandungan protein dan tingkat kecernaan yang tinggi untuk ruminansia adalah lamtoro (Leucaena leucocephala).

Setiap daerah di Indonesia memiliki keragaman dan potensi hasil lamtoro yang berbeda sebagai sumber hijauan pakan ternak. Lamtoro masih menjadi pilihan utama bagi peternak yang melakukan pemeliharaan secara intensif di dalam kandang. Selain keterbatasan lahan, karakteristik tanaman lamtoro berupa perdu yang dapat mencapai ketinggian 20 meter menjadikan peternak tidak tertarik untuk mengembangkannya sebagai tanaman di padang gembalaan.

Di Indonesia terdapat beberapa jenis lamtoro yang biasa dikenal oleh masyarakat diantara lamtoro kecil dan lamtoro gung (besar). Saat ini terdapat lamtoro hasil pemuliaan tanaman yaitu lamtoro kultivar Tarramba. Tarramba (Leucaena leucocephala cv. Tarramba) merupakan kultivar lamtoro hasil 
pemuliaan dari Australia yang diperkenalkan di Kupang (Nulik et al., 2013).

Tarramba memiliki ketahanan terhadap cekaman aluminium (Manpaki et al., 2017) serta lingkungan yang kering dan kutu loncat (Prihantoro et al., 2019). Lamtoro gung dengan morfologi tanaman yang tinggi besar dapat menjadi sumber makanan ternak dengan potensi hasil dan protein yang tinggi (Bageel et al., 2020), sedangkan lamtoro kecil dengan jumlah cabang yang banyak lebih umum digunakan sebagai sumber hijauan pakan ternak oleh masyarakat.

Pengembangan lamtoro sebagai HMT dapat meningkatkan produktivitas ternak, meningkatkan ketersediaan pakan serta meningkatkan pemanfaatan lahan sebagai bentuk konservasi (Shelton dan Dalzell, 2007). Adanya potensi yang besar dari lamtoro pada aspek-aspek tersebut mendorong pentingnya penelitian tentang potensi hasil lamtoro berdasarkan keragaan dan jenisnya dari beberapa lokasi di Indonesia.

\section{MATERI DAN METODE}

Percobaan dilaksanakan di Kebun Percobaan Badan Pengkajian dan Penerapan Teknologi (BPPT), Prumpung, Kec. Gunung Sindur, Kabupaten Bogor, Jawa Barat pada bulan Juli hingga Desember 2019.

Bahan tanaman yang digunakan adalah benih lamtoro Tarramba dari NTT, aksesi Yogyakarta, dan aksesi Serpong. Tarramba memiliki ukuran biji sedang, warna biji coklat terang dan bernas. Aksesi lamtoro dari Yogyakarta yang digunakan tergolong jenis lamtoro kecil (Leucaena leucocephala ssp. Leucocephala) dengan ciri ukuran biji kecil, warna biji coklat gelap hingga hitam mengkilat. Benih lamtoro dari Serpong yang digunakan termasuk jenis lamtoro gung (Leucaena leucocephala ssp. glabrata) dengan ciri biji besar, warna coklat terang dan rata.

Pupuk yang digunakan pada percobaan ini adalah NPK majemuk, pupuk daun, pupuk kandang sapi dan insektisida digunakan untuk mengendalikan hama kutu putih. Alat yang digunakan yaitu botol kultur, termometer, oven, bak semai, polibag, sprayer, alat tanam, penggaris, gunting tanam, label dan amplop kertas.

Percobaan disusun menggunakan rancangan acak kelompok (RAK) dengan tiga taraf perlakuan yaitu lamtoro Tarramba dari NTT (L1), aksesi Yogyakarta (L2), dan aksesi Serpong (L3) dengan masing-masing delapan ulangan. Data hasil pengamatan diuji dengan analisis sidik ragam dan apabila terdapat pengaruh nyata maka dilakukan uji lanjut menggunakan uji beda nyata terkecil (BNT).

Parameter pengamatan pertumbuhan dilakukan setiap dua minggu mulai 2 hingga 10 minggu setelah tanam (MST) meliputi tinggi tanaman, jumlah daun dan jumlah cabang. Pengamatan hasil panen meliputi bobot basah dan bobot kering edible portion. Panen dilakukan pada saat tanaman berumur 5 bulan setelah tanam (BST) dengan memotong batang tanaman setinggi $60 \mathrm{~cm}$ dari permukaan tanah dan memilah antara batang dengan edible portion. Pengukuran bobot basah edible portion dilakukan dengan menimbang bagian daun, batang muda, bunga dan buah saat panen. Bobot kering edible portion ditentukan dengan mengeringkan dalam oven suhu $105^{\circ} \mathrm{C}$ selama 72 jam. Proses pengeringan menggunakan metode dari Handayani et al. (2019) (data belum dipublikasikan).

Benih lamtoro yang digunakan adalah benih yang masak fisiologis dan memiliki kualitas baik dengan ciri-ciri biji bernas, mengkilat dan tidak terserang hama penyakit. Benih lamtoro yang telah disortir selanjutnya direndam dalam air bersuhu $70^{\circ} \mathrm{C}$ dan dibiarkan dingin hingga 24 jam. Benih ditiriskan kemudian ditanam pada bak semai dengan media tanah:pupuk kandang (1:1). Benih dijaga kelembabannya dengan disiram secara rutin serta diberikan nutrisi berupa pupuk NPK cair dosis $10 \mathrm{~g} / \mathrm{l}$ pada 20 hari setelah semai (HSS). Benih yang telah berkecambah dan berumur 4 minggu setelah semai (MSS) dipindahkan kedalam polibag diameter $10 \mathrm{~cm}$ $\times 15 \mathrm{~cm}$ berisi campuran tanah : pupuk kandang (1:1). Perawatan rutin dilakukan dengan penyiraman dan pembersihan gulma serta penyemprotan pupuk daun dosis $2 \mathrm{~g} / \mathrm{l}$ pada 35 HSS. Selanjutnya benih siap dipindahkan ke lahan percobaan saat berumur 6-7 MSS.

Lahan percobaan disiapkan dengan dibalik dan buat guludan, selanjutnya dibuat lubang tanam dengan jarak $1 \mathrm{~m} \times 2 \mathrm{~m}$. Pupuk kandang sapi dosis $1 \mathrm{~kg} /$ lubang tanam dimasukkan ke dalam lubang tanam 2 minggu sebelum pelaksanaan penanaman. Bahan tanaman dikeluarkan dari polibag dan ditanam pada lubang tanam kemudian ditutup menggunakan tanah disekitar lubang tanam. Pemeliharaan tanaman dilakukan dengan penyiraman dan penyiangan gulma secara teratur, pemupukan dengan NPK dosis 30 g/tanaman pada 4 minggu setelah tanam (MST). Serangan hama kutu putih pada tanaman lamtoro dikendalikan dengan insektisida Curacron dosis 0,5 $\mathrm{ml} / \mathrm{l}$ air.

\section{HASIL DAN PEMBAHASAN}

Pengamatan pertumbuhan lamtoro menunjukkan bahwa ketiga aksesi yang digunakan (Tarramba NTT, Yogyakarta dan Serpong) dapat beradaptasi dengan baik pada lahan percobaan di Prumpung. Hal ini diketahui dari pertumbuhan tanaman yang terus 
meningkat dari awal hingga akhir pengamatan.

Hasil analisis sidik ragam menunjukkan bahwa perlakuan aksesi lamtoro berpengaruh nyata terhadap tinggi tanaman pada semua waktu pengamatan, jumlah daun pada 2 dan 6 MST, jumlah cabang pada 8 MST (Tabel 1) serta bobot basah dan bobot kering edible portion pada 5 bulan setelah tanam (Tabel 2).

Aksesi Serpong (L3) memiliki nilai tinggi tanaman paling besar dibandingkan dengan aksesi lainnya dari awal hingga akhir pengamatan (Tabel 1). Nilai tinggi tanaman aksesi Serpong (L3) yaitu $170 \mathrm{~cm}$, diikuti Tarramba NTT (L1) 146,9 cm dan aksesi Yogyakarta (L2) $81,9 \mathrm{~cm}$ pada 10 MST. Nilai tinggi tanaman ini sejalan dengan karakter aksesi Serpong sebagai lamtoro gung (Leucaena leucocephala ssp. glabrata) yang memiliki keragaan tanaman tinggi dan batang yang besar. Bageel (2020), menyatakan bahwa lamtoro gung merupakan tanaman penting untuk agroforestri dapat tumbuh dengan cepat dan memiliki ketinggian hingga $20 \mathrm{~m}$.

Persentase tinggi tanaman dari Tabel 1, diketahui bahwa Tarramba memiliki nilai persentase pertambahan tinggi tanaman yang lebih besar dibandingkan aksesi Serpong dan aksesi Yogyakarta. Hal ini menunjukkan bahwa Tarramba dapat beradaptasi dengan baik terhadap lingkungan sehingga tumbuh dengan optimal. Penelitian Hendrati dan Hidayati (2018) menunjukkan bahwa Tarramba memberikan penampilan yang terbaik pada pengamatan tinggi tanaman dan parameter lainnya dibandingkan sembilan populasi lamtoro lainnya di Indonesia.

Pada pengamatan jumlah daun, aksesi Serpong (L3) meningkat seiring dengan peningkatan tinggi tanaman dan berbeda nyata pada 6 MST sebanyak 31,9 helai daun majemuk. Kemudian tidak berbeda nyata secara statistik dengan aksesi lainnya hingga 10 MST. Jumlah daun berhubungan erat dengan tinggi tanaman lamtoro. Pada pengamatan 8 MST menunjukkan bahwa aksesi Serpong (L3) menghasilkan nilai tinggi tanaman terbesar (107 cm) (Tabel 1), namun memiliki persentase penambahan jumlah daun terkecil dibandingkan aksesi lainnya. Hal ini diduga karena aksesi Serpong memiliki karakteristik tanaman yang besar sehingga pertumbuhan apikal lebih dominan dibandingkan pertumbuhan lateral pada masa vegetatifnya.

Data jumlah cabang menunjukkan bahwa pada 6 MST aksesi Yogyakarta (L2) memiliki jumlah cabang terbanyak (8,6 cabang) dibandingkan aksesi lainnya dan tidak berbeda nyata antar aksesi sampai pengamatan 10 MST (Tabel 1). Pada percobaan ini diketahui bahwa aksesi Yogyakarta memiliki tinggi tanaman terendah namun jumlah cabang yang tidak berbeda nyata dengan aksesi lainnya.

Hasil analisis sidik ragam terhadap data panen menunjukkan bahwa perlakuan aksesi lamtoro berpengaruh nyata terhadap bobot basah dan bobot kering edible portion (Tabel 3). Lamtoro aksesi Serpong (L3) menghasilkan bobot basah tertinggi sebesar 845,2 gram, lebih tinggi dibandingkan Tarramba (L2) sebesar 645,8 gram dan aksesi Yogyakarta yaitu 420,5 gram (Tabel 3). Aksesi Serpong termasuk dalam jenis lamtoro gung yang memiliki keragaan batang, cabang dan helai daun yang besar sehingga memiliki potensi hasil yang besar. Bageel et al. (2020) menyatakan bahwa lamtoro gung dapat dipelihara sebagai leguminosae sumber pakan ternak yang lebat dengan pemanenan berulang beberapa kali dalam setahun dengan produksi bahan kering mencapai 34 ribu ton per hektar per tahun.

Data pada Tabel 2 menunjukkan bahwa susut bobot terendah adalah pada Tarramba yang memiliki kadar air 66,3\%. Tarramba dari NTT diketahui sebagai tanaman yang tumbuh pada daerah marginal dengan waktu kering selama 8-9 bulan namun dapat tumbuh dangan optimal dan tahan terhadap kutu loncat (Pers. Comm Debora Kana Hau, 2018). Pada penelitian ini benih diperoleh dari NTT dengan lingkungan tumbuh yang kering namun tanaman tetap tumbuh dan menghasilkan biomassa cukup tinggi. Hal ini menunjukkan bahwa Tarramba memiliki performa

Tabel 1. Rerata Pertumbuhan Vegetatif Lamtoro pada Umur 2-10 Minggu Setelah Tanam (MST)

\begin{tabular}{ccccccc}
\hline Parameter & Perlakuan & $2 \mathrm{MST}$ & $4 \mathrm{MST}$ & $6 \mathrm{MST}$ & $8 \mathrm{MST}$ & $10 \mathrm{MST}$ \\
\hline Tinggi Tanaman (cm) & L1 (Tarramba NTT) & $13,5 \mathrm{~b}$ & $19,0 \mathrm{~b}$ & $36,4 \mathrm{~b}$ & $83,8 \mathrm{~b}$ & $146,9 \mathrm{~b}$ \\
& L2 (Aksesi Yogyakarta) & $10,5 \mathrm{c}$ & $14,4 \mathrm{c}$ & $26,1 \mathrm{c}$ & $53,1 \mathrm{c}$ & $81,9 \mathrm{c}$ \\
& L3 (Aksesi Serpong) & $21,3 \mathrm{a} *$ & $26,2 \mathrm{a}$ & $49,1 \mathrm{a}$ & $107,0 \mathrm{a}$ & $170,0 \mathrm{a}$ \\
Jumlah Daun (helai) & L1 (Tarramba NTT) & $6,7 \mathrm{a}$ & 13,5 & $25,4 \mathrm{~b}$ & 55 & 93,9 \\
& L2 (Aksesi Yogyakarta) & $5,5 \mathrm{~b}$ & 13,1 & $23,1 \mathrm{~b}$ & 49 & 88,1 \\
& L3 (Aksesi Serpong) & $6,9 \mathrm{a}$ & 15,9 & $31,9 \mathrm{a}$ & 55,5 & 98,5 \\
Jumlah Cabang & L1 (Tarramba NTT) & Belum dilakukan pengamatan & $3,6 \mathrm{ab}$ & 5,8 & $7,0 \mathrm{~b}$ & 10,4 \\
& L2 (Aksesi Yogyakarta) & Belum dilakukan pengamatan & $3,1 \mathrm{~b}$ & 5,4 & $8,6 \mathrm{a}$ & 11,7 \\
& L3 (Aksesi Serpong) & Belum dilakukan pengamatan & $4,1 \mathrm{a}$ & 5,2 & $6,5 \mathrm{~b}$ & 11,7 \\
\hline
\end{tabular}

*) huruf yang berbeda pada kolom yang sama menunjukkan berbeda nyata pada taraf $5 \%$ uji beda nyata terkecil 
Tabel 2. Rerata Bobot Basah dan Bobot Kering Lamtoro per Tanaman pada Umur Panen 5 Bulan Setelah Tanam (BST)

\begin{tabular}{ccccc}
\hline \multirow{2}{*}{ Perlakuan } & \multicolumn{2}{c}{ Rerata bobot edible portion (g) } & Selisih bobot basah & \multicolumn{2}{c}{$\begin{array}{c}\text { Kadar air edible por- } \\
\text { tion (\%) }\end{array}$} \\
\cline { 2 - 3 } & Bobot basah (a) & Bobot kering (b) & dan bobot kering (g) & 66,3 \\
L1 (Tarramba NTT) & $645,8 \mathrm{~b}$ & $217,4 \mathrm{~b}$ & $428,4 \mathrm{~b}$ & 67,3 \\
L2 (Aksesi Yogyakarta) & $420,5 \mathrm{c}$ & $137,7 \mathrm{c}$ & $282,8 \mathrm{c}$ & 67,7 \\
L3 (Aksesi Serpong) & $845,2 \mathrm{a}$ & $273,2 \mathrm{a}$ & $572,0 \mathrm{a}$ & 6 \\
\hline
\end{tabular}

Keterangan:

${ }^{*}$ ) huruf yang berbeda pada kolom yang sama menunjukkan berbeda nyata pada taraf $5 \%$ uji beda nyata terkecil
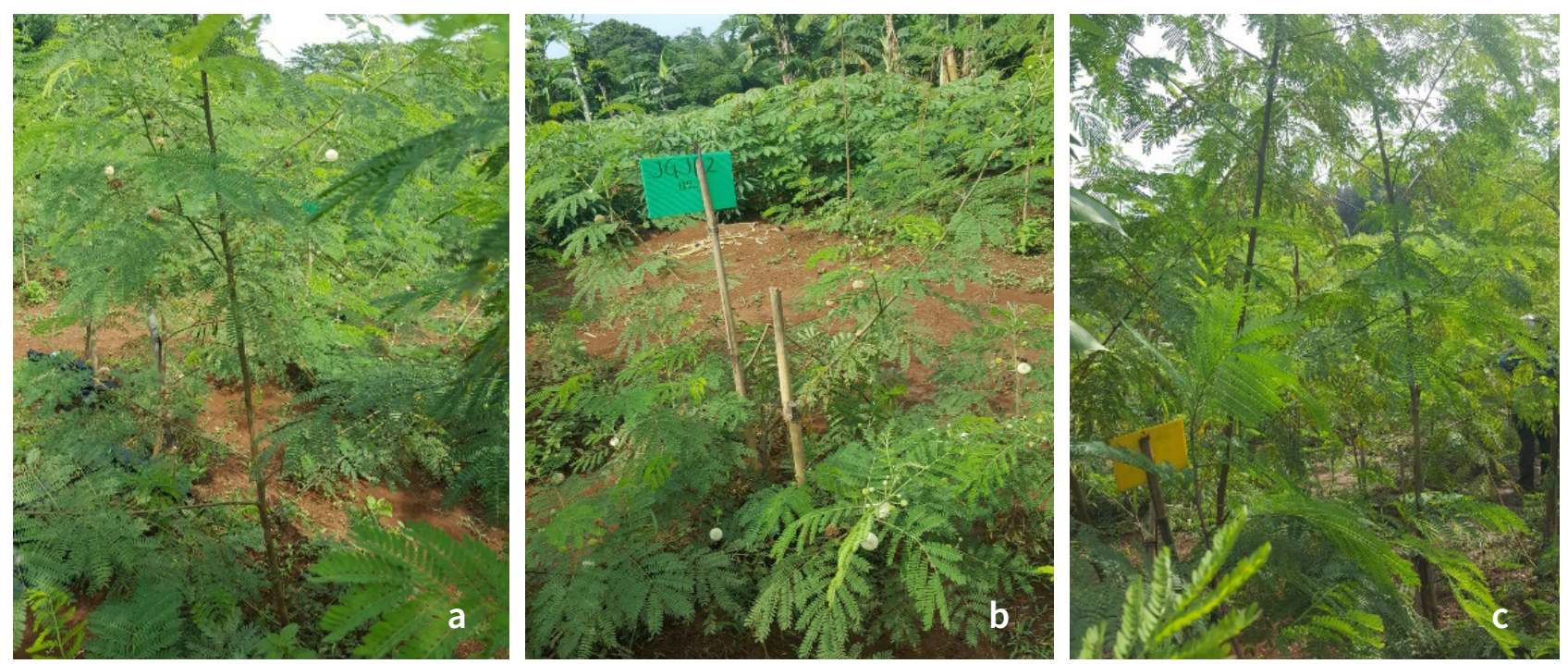

Gambar 1. Morfologi tanaman lamtoro kultivar Tarramba (a), aksesi Yogyakarta (b) dan aksesi Serpong (c)

serta kemampuan beradaptasi yang baik terhadap lingkungan.

Pengamatan morfologi dilakukan dengan memperhatikan data pertumbuhan vegetatif tanaman diantaranya tinggi tanaman, jumlah daun dan jumlah cabang. Pada percobaan ini diketahui bahwa Tarramba (L1) memiliki morfologi tanaman dengan ketinggian sedang, ukuran batang sedang, jumlah cabang banyak, serta ukuran helai daun sedang. Aksesi Yogyakarta (L2) memiliki morfologi tanaman dengan ukuran batang kecil, tanaman pendek, jarak antar buku sempit, jumlah cabang banyak, jumlah daun, bung dan buah kecil. Aksesi Serpong (L3) memiliki morfologi tanaman berupa batang besar, tanaman tinggi, jumlah cabang banyak, jarak antar buku lebar, serta ukuran daun, dan bunga/buah besar.

Pemanenan lamtoro Tarramba dan aksesi Yogyakarta relatif mudah dilakukan karena tinggi tanaman yang masih terjangkau dan batang tanaman yang relatif tidak keras, namun pemanenan aksesi Serpong cukup sulit karena tanaman yang relatif tinggi dan batang berkayu. Apabila dilakukan pemanenan untuk pakan ternak, maka Tarramba dan aksesi Yogyakarta dapat langsung dimakan ternak dengan cara digembalakan, namun pada aksesi Serpong perlu bantuan tenaga manusia sehingga ternak tidak akan terluka saat mengambil daun lamtoro yang tinggi.
Hal ini menunjukkan bahwa lamtoro Tarramba dan aksesi Yogyakarta berpotensi sebagai lamtoro pada padang gembalaan (pola ektensif) sedangkan aksesi Serpong yang tergolong lamtoro gung berpotensi dikembangkan sebagai bahan pakan ternak dengan proses panen dibantu oleh manusia (pola intensif).

\section{SIMPULAN DAN SARAN}

1. Perlakuan lamtoro Tarramba, aksesi Yogyakarta (Leucaena leucocephala ssp. Leucocephala) dan aksesi Serpong (Leucaena leucocephala ssp. glabrata) memberikan hasil yang berbeda nyata pada tinggi tanaman, bobot basah dan bobot kering edible portion.

2. Aksesi Serpong (Leucaena leucocephala ssp. glabrata) menghasilkan nilai terbesar pada parameter tinggi tanaman, bobot basah dan bobot kering edible portion

3. Hasil pengamatan morfologi tanaman mengindikasikan bahwa Tarramba dan aksesi Yogyakarta dapat digunakan sebagai tanaman untuk padang gembalaan (pola pemeliharaan ekstensif) sedangkan aksesi Serpong dapat digunakan untuk sumber hijauan pakan ternak dengan proses panen menggunakan bantuan manusia (pola pemeliharaan intensif) 


\section{DAFTAR PUSTAKA}

Bageel, A., M. D. H. Honda, J. T. Carrilo, dan D. Borthakur. 2020. Giant luecaena (Leucaena leucocephala subsp. glabrata): a versalite treelegume for sustainable agroforestry. Agroforestry Systems Vol. 94:251-268.

BPS. bps.go.id. 2020. https://databoks.katadata. co.id/datapublish/2020/02/14/tren-produksidaging-sapi-indonesia-menurun. Diunduh pada 23 Juli 2020.

Hendrati, R. L., dan N. Hidayati. 2018. Sembilan populasi Leucaena leucochepala (lam.) de wit. asal Indonesia untuk pemuliaan kayu energi versus var. Tarramba. Jurnal Pembenihan Tanaman Hutan. Vol 6(1):15-30.

Manpaki, S. J., P. D. M. Karti, dan I. Prihatoro. 2017. Respon pertumbuhan eksplan tanaman lamtoro (Leucaena leucocephala cv. Tarramba) terhadap cekaman kemasaman media dengan level pemberian aluminium melalui kultur jaringan. Jurnal Sain Peternakan Indonesia Vol. 12(1):7182.
Nulik, J., Dahlanuddin, D. K. Hau, C. Pakereng, R. G. Edison, D. Liubana, S. P. Ara, dan.E. Giles. 2013. Establishment of Leucaena leucocephala cv. Tarramba in eastern Indonesia. Tropical Grasslands - Forrajes Tropicales. 2013. Volume $1,111-113$.

Prihantono, I., S. J. Manpaki, P. D. M. H. Karti. 2017. Karakteristik pertumbuhan Leucaena leucocephala cv. Tarramba tercekam aluminium pada sistem kultur jaringan. Pastura Vol. 7(1):1013

Prihantoro, I., A. Anandia, A.T. Aryanto, dan P. D. M. H. Karti. 2019. Karakteristik morfologi kalus lamtoro (Leucaena leucocephala cv Tarramba) teradaptasi pH 3.4 hasil iradiasi sinar gamma 40gy berdasarkan perbedaan sumber sitokinin (kinetin,BAP,TDZ) pada kultur jaringan. Pastura Vol.8(2):63-68.

Shelton, M., dan Dalzell, S. 2007. Production, economic and environmental benefit of leucaena pastures. Tropical Grassland Vol. 4 